\title{
MARKET POSITIONING AND INFLUENCE OF TOURIST DESTINATIONS DEVELOPING EDUCATIONAL TOURISM
}

\author{
Iveta Voleva-Petrova ${ }^{1}$
}

Received: 28.09.2020, Accepted: 20.10.2020

\begin{abstract}
This report main aim is to represent and emphasize the market positioning and influence of tourism destinations developing educational tourism. Main research goals are to define the specification of the tourism market, define educational tourism, to identify the specification of the educational tourism market, and also to represent the methodology for positioning and building marketing influence in tourism destination suggested by the author. The suggested methodology is based on the examined academic literature concerning the positioning of tourist products on the market, the author presents his vision for the main stages for the successful positioning of destinations.
\end{abstract}

Keywords: educational tourism, tourism market, positioning, market influence

JEL Codes: I23, Z32, Z33, L11

\section{Introduction}

Tourism is one of the fastest developing economic sectors in the world. Tourism is the main economic power in any country. There are different types and form of tourism. Educational tourism is one specific form that is related to a combination of educational and tourism products. Educational tourism is a great opportunity for any country that has already a stable position in the tourism market but also have quality educational products. Educational tourism is a great opportunity for attraction specific market segments.

\section{Tourism market}

It is important to clarify some basic concepts related to the tourism market.

The market, in general, can be defined as a place for transactions and trade operations, commodity-money transactions or non-cash exchange or as a center for the exchange of products, services, ideas and money.

\footnotetext{
${ }^{1}$ Southwest University "Neofit Rilski" Blagoevgrad, PhD student. e-mail: i.voleva@swu.bg; ORCID ID: https://orcid.org/0000-0002-9242-7954
} 
The tourist market is an abstract construction that reflects the relationship between tourist demand and tourist supply. In principle, market relations are not abstract in real life, but due to the specifics of tourism products, the tourism market must be a symbol of abstract market relations (Neshkov et al., 2001).

The tourist market is the "place" where the connection between the demand and supply of tourist goods and services manifests itself. In the tourist market, several tourist companies come into direct contact with their customers and sell tourist products that are related to tourist travel.

The national tourist market can be emitting and receptive. However, this distinction is only conditional and is based mainly on the fact that the tourist demand is in the territory of the permanent residence of the tourists, and the tourist supply has a certain tourist place where the consumption of tourist goods and services is realized.

The emitting tourist market is the permanent residence of the tourists and the living conditions give rise to tourist needs. In this area there are no suitable conditions to meet these needs and thus the tourist demand is formed, which in turn is directed to other places (Neshkov et al., 2001).

In this sense, the receptive tourist market is a territory whose characteristic feature is the availability and possession of tourist resources and conditions that could meet the tourist needs and immediately thereafter realize the tourist consumption.

International tourism markets are highly segmented according to the different types of tourism products, according to customers and their needs, as well as depending on the destinations. The international tourism market is divided into several regions, which compile and contribute to the complete analysis of the tourism market (Neshkov et al., 2001).

The necessary analysis for each of the tourist regions is carried out to achieve specific goals. These analyzes help to more easily and accurately identify the leading tourist destinations in which there is an increase in interest and consumption of tourist products, and on the other hand identify destinations with a decline in tourist consumption and interest. One of the main characteristics of tourist consumption is its uneven distribution, namely, through such analyzes the concentration is determined and the big differences in the different geographical regions are established. With the help of this type of analysis, experts can identify potentially important countries that, internationally, have great potential to become leading and important tourist destinations, and the development of tourism will contribute positively to their economic and social development. 


\section{Educational tourism}

First of all, it is important to define the term 'education'. According to Smith (1982), education can be defined as "an organized, systematized process for promoting learning, providing the necessary conditions and activities through which the learning process itself can take place."

Some authors, such as Kidd (1973) and Smith (1982), believe that there is no precise definition of training, as it can be referred to in three different directions. In the first place, it is a product of training, where the result is important. In second place is the learning process itself, which occurs during learning and gaining new knowledge. The third is the function itself or the actual actions that reinforce the knowledge gained.

There are many and varied forms and types of tourism. To a large extent, the type of tourism is determined by the purpose of the trip. One such type of tourism is youth tourism. According to some authors, educational tourism is a form of youth tourism. Youth tourism does not have a clear and specific definition.

Educational tourism is a niche type of tourism and due to this specificity, it is not widespread in the tourist market. Educational tourism and its supply are aimed at certain market segments, which are often significantly smaller, in contrast to the segments of mass tourism.

According to Haigh (1995), youth tourism is a type of tourism in which young travellers prefer budget accommodation, with an emphasis on meetings with other young travellers. This trip can be individual or organized, with flexible travel schedules with a longer duration than traditional leisure and recreation trips.

Ritchie (Ritchie, et al., 2003) defines educational tourism as "A tourism activity undertaken by individuals who travel on one or more nights with a primary or secondary purpose of education and learning. This definition gives a broader and more comprehensive picture of educational tourism, not only as tourism related to the travels of pupils and students but also individuals who wish to enrich their knowledge.

According to the World Tourism Organization (UNWTO, 2019), educational tourism is considered as a form of tourism that encompasses different types of tourism, which are related to the motives of tourists to travel, participate and engage themselves in various training, self-improvement processes, intellectual growth and the development of different and diverse skills. Educational tourism represents a wide range of products and services related to 
academic research, skills acquisition holidays, school trips, sports training, career development courses and language courses, among others.

\section{Market system of educational tourism}

Richie illustrates the tourist demand and supply of educational tourism. It also identifies the factors that influence the two elements of the educational tourism market (Ritchie et al., 2003).

On the one hand, the elements that determine the tourist demand for educational tourism are:

- Demographic characteristics

- Tourist behaviour

- Motivation

- Perceptions that are based on already gained life experience

On the supply side, Ritchie points to several key elements that shape the supply of educational tourist destinations (Ritchie et al., 2003):

- The primary tourist product

- Destination marketing and management structure

- Environment and available resources on the territory of the destination

The figure shows two main elements that have a direct impact on decisionmaking and these are:

- Personal influence

- Influence of the destination

Researcher Ritchie identifies two main components that underlie the supply of educational destinations: the main tourism product and secondary or also known as complementary elements (Ritchie et al., 2003). According to the Tourism Commission, these elements are combined differently by organizations in order to create educational tourism products.

Different organizations combine the main tourist products for the purposes of educational tourism. These elements are:

- Tourist attractions and events that are a place to learn and gain certain knowledge. This group includes various historical sites, zoos, archaeological excavations, museums, and a number of other tourist attractions.

- Specialists who provide teaching and provide the necessary information. This group includes teachers, researchers, guides, curators, translators, teachers, and others. 
- Tour operators who plan and organize tourist trips for tourists participating in educational trips. They offer organized trips with a total price to the destination, tour guide services and other tourist activities.

- Tourism programs developed by organizations that support the process of training tourists. These programs are developed by universities, language schools, specialized interest groups and others.

The secondary services that complement the main product are also important for tourists in educational tourism. These products are:

- Transport services. These services can be independent or included in the package price. These are different means of transport that can be used to reach the destination.

- Hotel services. They may also not be included in the package.

- Tourist services. Various insurance companies, travel agencies are included, which offer additional trips on the territory of the educational destination.

- Destination marketing. This is extremely important for the promotion of the destination as an educational one. It is necessary to build a marketing plan that aims to promote and advertise the destination at national, regional and even international level.

The development of educational tourism in a destination depends entirely on the combination of the first and secondary elements. One of the most important things for market positioning and establishing market influence is the continuous development of the innovation process, building a partnership network, developing and promoting the products of educational tourism (Canadian Tourism Commission, 2001).

As can be seen in the figure no.1, the fact that many of the organizations are not tourism companies and tourism is not their main business can quite effectively limit the management and development of this type of tourism. Such organizations, for example, various educational institutions such as universities, colleges, language schools and others. These are just some of the organizations involved in creating the product of educational tourism. Precisely because their main goal is education, not tourism, and this makes the dissemination and promotion of this type of tourism extremely difficult (Canadian Tourism Commission, 2001). 
Figure no. 1 Market structure of educational tourism

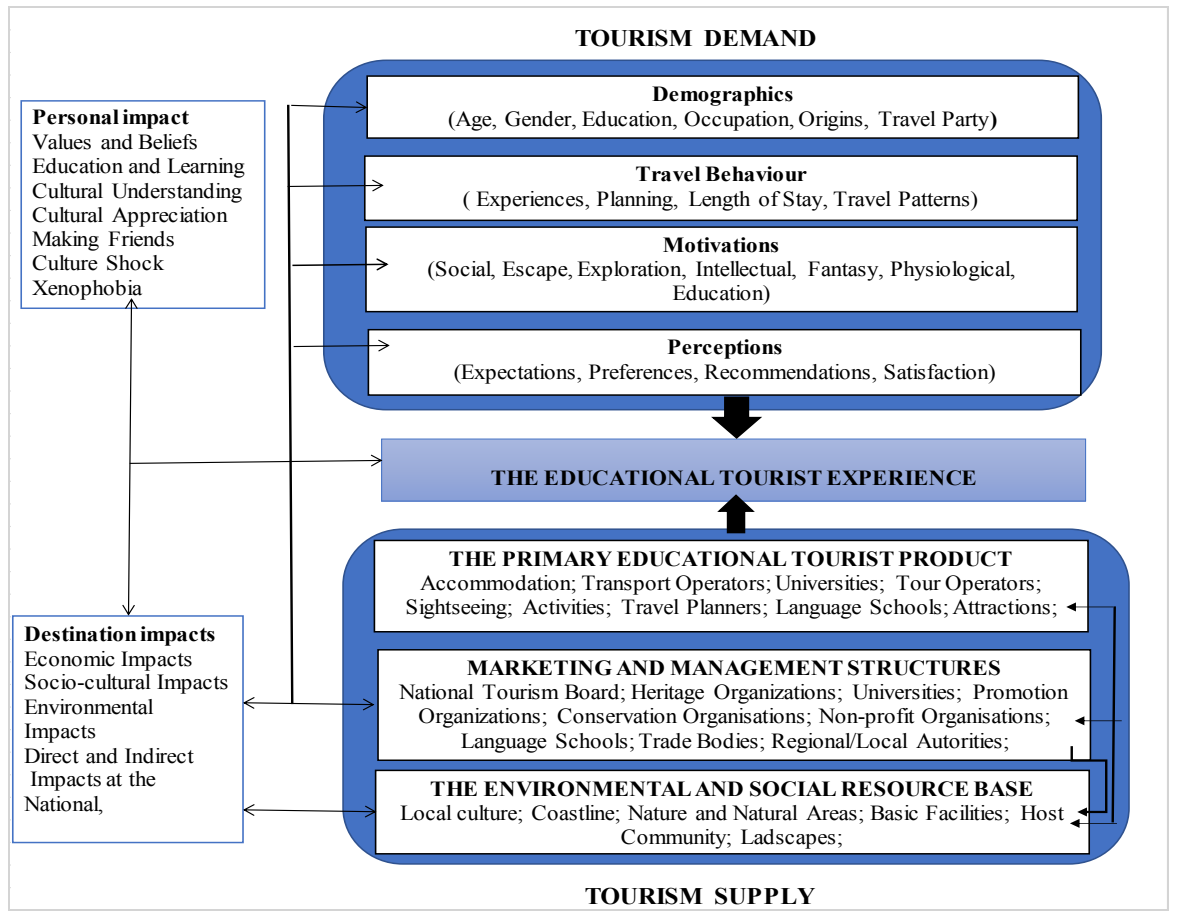

Source: Ritchie, B., Carr, N., \& Cooper, C. (2003). Managing Educational Tourism. Clevedon, United Kingdom: Channel View Publications.

5. Positioning and market influence of tourist destinations developing educational tourism

In the development of tourism and the spread of new destinations and their entry into new markets, it is becoming increasingly difficult for tourists to distinguish destinations from each other and their positioning is becoming increasingly difficult. For this, the destination needs to base its positioning on physical characteristics such as climate, geographical location, services and infrastructure or specific landmarks and characteristics.

Given that more tourist destinations are similar in the specific characteristics listed, increasing weight in the decision of consumers affects the emotional reactions and experience. It is the same with educational tourist destinations. However, their specificity was played by education and development, which is the motive for attracting tourists to them. 
The positioning of the brand is closely related to the segmentation of the tourist market. We have already said that tourist markets are many and varied in type and speciality, but not every market can be well positioning a destination.

Positioning is important because of the need to establish and maintain a favourable and distinctive place in the minds of the target segments. This will help set the destination apart from everyone else. (Kotler P. a., 2002)

The concept of positioning is focused on three main areas - market segments, the brand image of the destination in different segments and its competitive advantages. These competitive advantages need to be clearly emphasized in the positioning of the brand in each of the selected segments. (Aaker, 1982).

According to the Economic Encyclopaedia, market influence is also known as market power. For the research, we can define the market influence as the ability of a company to determine the price of its products, at the same time to increase and regulate it without actually having a negative impact on the number of customers (Collective, 2005).

\section{Methodology of positioning and building market influence of educational destinations}

About successfully positioning of tourist destination on the market and have a market influence, it is necessary to go through several stages.

Based on the analysed academic literature concerning the positioning of tourist products on the market, the author presents his vision for the main stages for the successful positioning of destinations are:

- Effective destination management

- Availability of the necessary resources for the development of educational tourism.

- Market segmentation and market assessment

- Market forecasting

- Building a brand and image

- Destination marketing - analysis through several marketing tools.

- Development of the tourist product

- Building market influence

First, the effective management of tourism is very important for positioning in the tourism market with new tourism products.

Management for tourism organizations is often organized by the destination management organization. The World Tourism Organization defines 
the destination management organization as a leading organization in the tourism sector, including various bodies, stakeholders and professionals. This organization of authorities aims to facilitate and improve collective work and to achieve partnership between individual countries interested in the implementation of tourism (World Tourism Organization, 2019)

The functions of the destination management organization can change at different management levels - national, regional and local. The main function of this type of organization is to assess the current state of tourism development of the destination, to organize meetings between stakeholders - government, civil society and private organizations (World Tourism Organization, 2019).

There are many and varied functions and responsibilities that the management organizations of the tourist destination can provide. Every tourist destination has this type of organization, but in order to be successfully spread in tourism, it is necessary to turn to a person. Despite the lack of this organization, some answers need to be included in the destination management strategy (World Tourism Organization, 2019).

Second, it is important to have the necessary resources - tourism and education.

Educational tourism is specific and affects certain market niches. In order to develop educational tourism in the territory of a destination, it is necessary to have certain resources. Both tourism and educational resources must be available.

Due to this feature of educational tourism, only certain tourist destinations have the necessary resources to offer and develop it.

In order to position itself on the market as an educational tourist destination, it is necessary to have both types of resources - tourist and educational. Therefore, not every tourist destination can be positioned on the tourist market as an educational one.

The traditional tourist product in order to be created and offered to potential visitors requires the availability of certain groups of resources. On the one hand are the tourist resources, which are divided into two main groups - anthropogenic and natural.

The second most important is the educational product. The quality of the product depends on the quality of education that the institutions provide. It is important to note that in addition to quality, it is important that the product is accessible. By affordable is meant that the product must be at a good price that is appropriate for the market segment that aims to be attracted to the destination. Also, accessibility is expressed in the location of the destination. This aspect includes the legal regime for visiting the destination. Quite often, in some 
countries, it is necessary to issue a visa to access it. This is a factor that contributes to attracting consumers. If the destination is affordable, in addition to financial, it provides an opportunity to be better positioned in the market.

In order to achieve success as an educational tourist destination, it is necessary to study in detail the target customers. During this stage, attention is focused on key target markets that will generate a higher percentage of visitors. To this end, it is necessary to conduct a detailed study to identify and understand the main target markets. In order to achieve the goal and the position to be successfully positioned in these target markets, it is necessary to have a strong impact on market segments.

Market research is the key tool for identifying the needs and desires of the target visitors, both in terms of tangible products such as accommodation and attractions and intangibles such as various experiences, entertainment or education. In this process, it is important to pay attention to the emotional motive. In educational tourism, it is also possible that the choice of destination is tied to emotion.

Market forecasting provides an opportunity for destination managers to explore opportunities for development and building better market influence. Forecasting makes it possible to determine the leading trends in the movement of the number of foreign students who have chosen the destination. If an increase in the number of international students is envisaged, it is necessary to make improvements in the product, with the aim of meeting the needs.

Building the image is one of the important steps towards positioning and increasing the market share of the educational destination on the market. Creating a unique identity is important for the destination. As an educational tourist destination, it needs to be different from its competitors. This is achieved by creating a unique product that is a combination of tourism and education. Identity makes the destination more easily recognizable among competitors in the market.

Branding a tourist destination as an educational one will significantly contribute to increasing the market share of educational tourists. Good and effective branding helps to provide information and generates greater market demand.

The educational tourist product is a combination of various elements that create a complete experience that can be offered to potential visitors. On-site experiences at the destination include intangible features (educational products and services, unique events, attractions, quality of the environment, service levels, kindness to people, etc.) as well as material aspects such as public 
infrastructure, private products and services, public attractions and services, community lifestyle, attractions, etc.

\section{Conclusion}

Educational tourism is a great opportunity for tourism destination who has already a stable position in the tourism market. This type of tourism can be the development of any country which has educational and tourism resources. There is a need for interaction between different institutions - educational and tourism. It is necessary for the development of the educational product. Some educational destinations are working on developing a good educational tourism product that is going to attract many visitors. Positioning and developing market influence is not an easy task but it is achievable.

\section{REFERENCES}

Aaker, D. a. (1982). Positioning your product. Business Horizons 25.

Canadian Tourism Commission (CTC). (2001). Learning Travel: 'Canadian EdVentures' Learning Vacations in Canada: An Overview. Canadian Tourism Commission.

Collective. (2005). Economic Encyclopedia. Science and art.

Haigh, R. (1995). Backpackers in Australia. Canberra: Bureau of Tourism Research.

Kidd, J. R. (1973). How adults learn. Chicago: Follett.

Kotler, P. a. (2002). Country as brand, product, and beyond: a place marketing and brand management perspective. Journal of Brand Management 9, 249-261.

Neshkov, M., Rakadzhiyska, S., Dabeva, T., Marinov, S., Mileva, M., \& Kazadjieva, V. (2001). Introduction to tourism. Varna: University Publishing House University of Economics - Varna.

Smith, R. (1982). Learning how to learn. Chicago: IL: Follett.

Ritchie, B., Carr, N., \& Cooper, C. (2003). Managing Educational Tourism. Clevedon, United Kingdom: Channel View Publications. 
World Tourism Organization. (2019). UNWTO Guidelines for Institutional Strengthening of Destination Management Organizations (DMOs) Preparing DMOs for new challenges. Madrid: https://doi.org/10.18111/9789284420841.

World Tourism Organization (UNWTO). (2019). UNWTO Tourism Definitions. Madrid, Spain: World Tourism Organization (UNWTO) https://doi.org/10.18111/9789284420858.

World Tourism Organization (UNWTO). (2007). A Practical Guide to Tourism Destination Management. Madrid: UNWTO. 